Наносистели, нанолатеріали, нанотехнології Nanosistemi, Nanomateriali, Nanotehnologii 2018, т. 16, № 4, сc. $713-718$ (c) 2018 ІМФ (Інститут металофізики ім. Г. В. Курдюмова НАН України) Надруковано в Україні. Фотокопіювання дозволено тільки відповідно до ліцензії

PACS numbers: 78.56.-a, 78.66.Jg, 81.15.-z, 84.60.Jt, 88.40.hj, 88.40.jm

\title{
Impact of Antireflective Coating on the Characteristics of a-Si:H Solar Cells
}

\author{
B. Zaidi ${ }^{1}$, S. Belghit ${ }^{1}$, C. Shekhar ${ }^{2}$, B. Hadjoudja ${ }^{3}$, and B. Chouial ${ }^{3}$ \\ ${ }^{1}$ Department of Physics, Faculty of Material Sciences, \\ University of Batna 1, \\ 05000 Batna, Algeria \\ ${ }^{2}$ Department of Applied Physics, \\ Amity University Gurgaon, \\ 122413 Haryana, India \\ ${ }^{3}$ Laboratory of Semiconductors, Department of Physics, \\ University of Badji Mokhtar, \\ B.P. 12, 23000 Annaba, Algeria
}

Nowadays, the thin film solar cells of amorphous silicon have mostly been used because of their low cost. During these last decades, the performances of these cells have been greatly improved. In this work, we investigate the effect of the thickness of antireflective coating (ARC) on the characteristics of a solar cell based on a $\mathrm{p}-\mathrm{i}-\mathrm{n}$ (PIN) structure. All these options are implemented in the one-dimensional numerical simulation program SCAPS-1D developed at the Department of Electronics and Information Systems (ELIS) of the University of Gent, Belgium.

У наш час тонкоплівкові сонячні комірки аморфного кремнію головним чином використовувалися через їхню низьку ціну. Протягом минулих десятиліть були значно поліпшені експлуатаційні якості цих комірок. У цій роботі ми досліджуємо вплив товщини просвітлювального покриття на характеристики сонячної комірки, заснованої на p-i-n-структурі. Усі ці варіянти здійснено в одновимірній числовій програмі моделювання SCAPS-1D, яку було розроблено в лабораторії електроніки й інформаційних систем Гентського університету (Бельгія).

В наше время тонкоплёночные солнечные ячейки аморфного кремния главным образом использовались из-за их низкой цены. В течение прошлых десятилетий были значительно улучшены эксплуатационные качества этих ячеек. В этой работе мы исследуем влияние толщины просветляющего покрытия на характеристики солнечной ячейки, основанной на p-i-n-структуре. Все эти варианты осуществлены в одномерной числовой программе моделирования SCAPS-1D, разработанной в лаборатории элек- 
троники и информационных систем Гентского университета (Бельгия).

Key words: thin film, PIN structure, solar cells, amorphous silicon, SCAPS-1D.

Ключові слова: тонка плівка, p-i-n-структура, сонячна комірка, аморфний кремній, SCAPS-1D.

Ключевые слова: тонкая плёнка, p-i-n-структура, солнечная ячейка, аморфный кремний, SCAPS-1D.

(Received 13 October, 2018; in final version, 9 November, 2018)

\section{INTRODUCTION}

The silicon in its monocrystalline and polycrystalline form needs to be almost hundred times thicker than a-Si:H in order to absorb the same amount of solar radiation [1-8]. The first types of solar panels developed in the laboratory used monocrystalline silicon (pure silicon crystal). In the laboratory, a simple p-n-junction of monocrystalline silicon is sufficient to achieve efficiencies of more than $20 \%$. Other types of silicon have been explored such as hydrogenated amorphous silicon a-Si: $\mathrm{H}$, which has a gap of $1.7 \mathrm{eV}$ and can be produced by thin-film deposition. a-Si:H hydrogenated amorphous silicon solar cells have been extensively studied for use as inexpensive solar cells [9-13]. The practical use of a-Si:H solar cell is as a power source and requires improvements in absorption coefficient and stability. In this study, we used SCAPS to investigate the effect of antireflective coating (ARC) on the characteristics of a-Si:H PIN solar cells (current density of short circuit $J_{\mathrm{sc}}$, open circuit voltage $V_{\text {co }}, P(V), Q E(\%)$, and $\left.C(V)\right)$.

\section{NUMERICAL MODELLING AND MATERIAL PARAMETERS}

The composition of a-Si:H PIN cell from top to bottom is composed as follows (Fig. 1):

\begin{tabular}{|c|}
\hline $\mathrm{ZnO}$ or $\mathrm{PbO}$ \\
\hline n-type a-Si:H \\
\hline Intrinsic a-Si:H \\
\hline p-type a-Si:H \\
\hline Ag/glass \\
\hline
\end{tabular}

Fig. 1. Structure of solar cell. 
- a transparent conductive film $(\mathrm{ZnO})$ or $(\mathrm{PbO})$;

- three layers of amorphous silicon, in the sequence, $n, i$, and $p$;

- a substrate made of $\mathrm{Ag} / \mathrm{glass}$.

In this paper, we use a Solar Cell Capacitance Simulator (SCAPS1D) of structures to analyse the a-Si:H solar cells. SCAPS is Windows application software [14]. It was developed to simulate the electrical characteristics of heterojunction solar cells and thin film. It has been extensively tested in solar cells by M. Burgelman et al. $[15,16]$.

\section{RESULTS AND DISCUSSION}

The structural response of the a-Si:H junctions solar cells as a function of wavelength of the incident radiation on the antireflective coating (ARC) is presented in Fig. 2. The quantum efficiency of the $\mathrm{ZnO}$ and $\mathrm{PbO}$ based solar cells is similar varying between 0 to $87.1 \%$. The maximum value is obtained at $590 \mathrm{~nm}$ wavelength. The efficiency is $67 \%$ at the radiation of $300 \mathrm{~nm}$ and increases gradual-

TABLE 1. Physics Parameters used in our simulation.

\begin{tabular}{ccccccc}
\hline Parameters & p-type a-Si:H & Intrinsic a-Si:H & n-type a-Si:H & $\mathrm{ZnO}$ & $\mathrm{PbO}$ \\
\hline $\begin{array}{c}\text { Thickness, } \mathrm{nm} \\
\text { Relative }\end{array}$ & 9 & 500 & 20 & 200 & 200 \\
permittivity & 11.9 & 11.9 & 11.9 & 9 & 10 \\
$\begin{array}{c}\text { Electron } \\
\text { affinity, eV }\end{array}$ & 3.9 & 3.9 & 3.9 & 4.6 & 4.5 \\
$E_{g}, \mathrm{eV}$ & 1.8 & 1.8 & 1.8 & 3.3 & 2.5 \\
$\mathrm{Nd}, \mathrm{cm}^{-3}$ & $10^{6}$ & $10^{6}$ & $10^{17}$ & $10^{18} 2.2 \times$ & $10^{18} 2.2 \times$ \\
$\mathrm{Na}, \mathrm{cm}^{-3}$ & $10^{17}$ & $10^{6}$ & $10^{6}$ & $10^{19} 1.8 \times$ & $10^{19} 1.8 \times$ \\
\hline
\end{tabular}

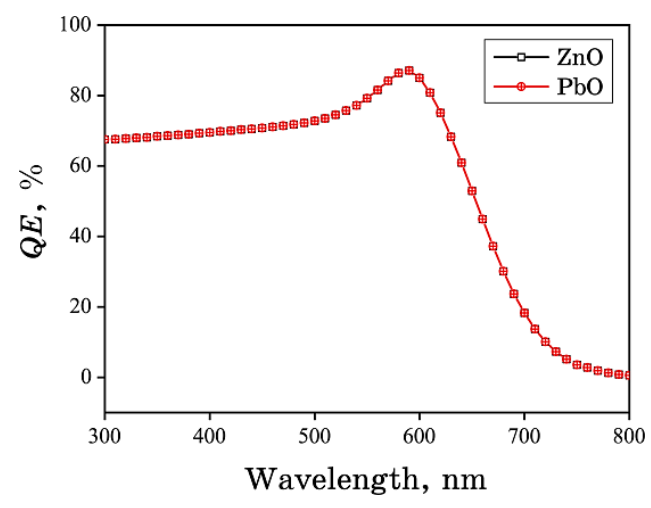

Fig. 2. Spectral response of our simple a-Si:H junction cells as a function of wavelength. 
ly with the increase in the wavelength to reach a maximum at 590 $\mathrm{nm}$ to $87.1 \%$ and thereafter. These results therefore indicate that, for the cells based on a-Si:H, the transport properties of the thin film materials are good enough to allow a good collection of the carriers. Interestingly, the improvement in the spectral response occurs not only in the visible region but also in the IR region. This improvement is larger for the microcrystalline emitter cell confirming the bigger improvement of the short-circuit current.

The change in the current density is shown in Fig. 3. The current density, $J$, decreases with antireflective coating as the voltage is increased initially gradually to $\mathbf{0 . 6}$ and, after that, more rapidly that clearly reflects the relationship between the electrical field and voltage. The initial efficiency of both cells is similar with similar open circuit voltages $\left(V_{\text {oc }}\right)$. After application of the $\mathrm{ZnO}$ :Al layers,

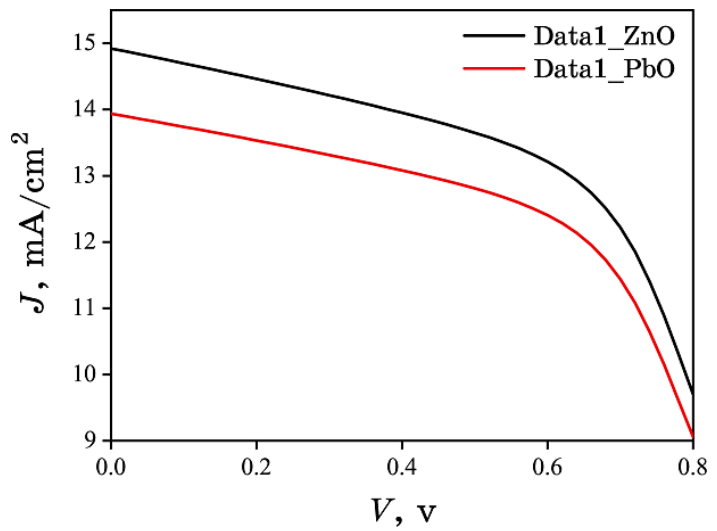

Fig. 3. Effect of antireflective coating on $J(V)$ characteristics.

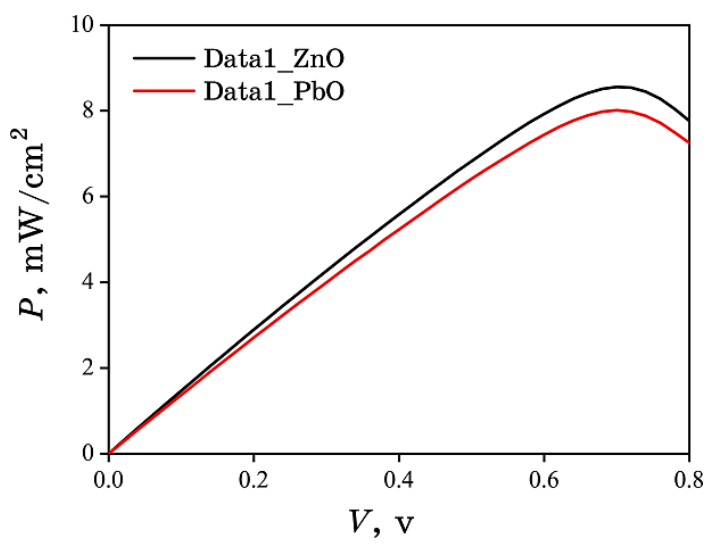

Fig. 4. Effect of antireflective coating on $P(V)$ characteristics. 
TABLE 2. Solar cell performance parameters calculated with SCAPS-1D $(\mathrm{ZnO} / \mathrm{a}-\mathrm{Si}: \mathrm{H})$ and $(\mathrm{PbO} / \mathrm{a}-\mathrm{Si}: \mathrm{H})$.

\begin{tabular}{c|c|c}
\hline Parameters & ZnO/a-Si:H & $\mathrm{PbO} / \mathrm{a}-\mathrm{Si}: \mathrm{H}$ \\
\hline$I_{\mathrm{sc}}, \mathrm{mA} / \mathrm{cm}^{2}$ & 14.92 & 13.94 \\
$V_{\text {oc }}$, volt & 0.98 & 0.888 \\
$F F, \%$ & 53.9 & 44.7 \\
\hline
\end{tabular}

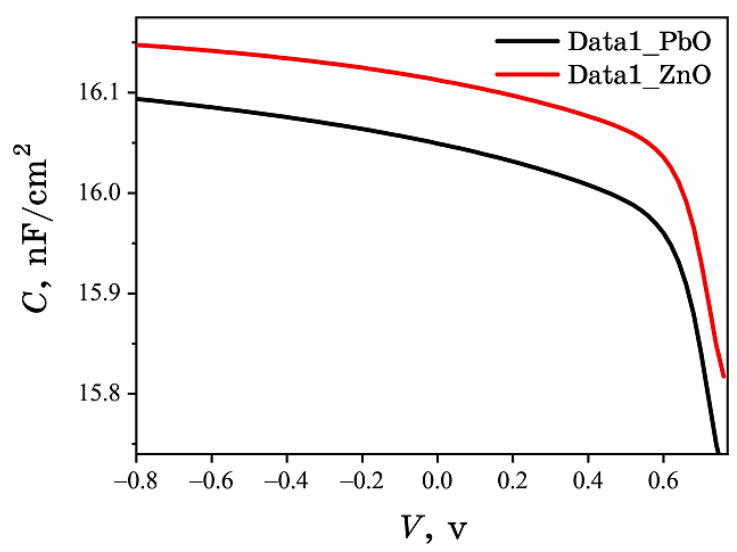

Fig. 5. Effect of antireflective coating on $C(V)$ characteristics.

the short circuit current density $\left(J_{\text {sc }}\right)$ shows a significant increase for both cells due to the antireflective effect of the coatings. The $V_{\text {oc }}$ also increases by a similar amount for both cases.

The variation of the power density generated by the two different configuration of the solar cell as a function voltage is presented in Fig. 4. As seen in this figure, the power density increases linearly to a maximum of $\cong 9 \mathrm{~mW} / \mathrm{cm}^{2}$.

The performance parameters of the two configurations of the solar cells are presented in Table 2.

The variation of the capacitance of the two configurations is presented in Fig. 5. The variation of the capacitance with the voltage is similar to the variation of the current density as presented above, though the capacitance is more for the solar cell with $\mathrm{ZnO}$ transparent layer apparently due to the lower charge carrier concentration in the layer.

\section{CONCLUSIONS}

The effect of the antireflection coating on the performance of the solar cells with the layered configuration as mentioned above has been studied in the present study. The current density, power den- 
sity, and capacitance as functions of the voltage show two distinct regions and change the behaviour near $V=0.7 \mathrm{~V}$. The quantum efficiency is maximum at $590 \mathrm{~nm}$.

\section{ACKNOWLEDGEMENTS}

We gratefully acknowledge to Dr. Marc Burgelman, University of Gent, Belgium, for providing the SCAPS-1D simulation software.

\section{REFERENCES}

1. B. Zaidi, S. Belghit, C. Shekhar, M. Mekhalfa, B. Hadjoudja, and

B. Chouial, Journal of Nano- and Electronic Physics, 10: 1 (2018).

2. P. Panek, M. Lipinski, E. Beltowska-Lehman, K. Drabczyk, and R. Ciach, Opto-Electronics Review, 11: 269 (2003).

3. B. Zaidi, B. Hadjoudja, B. Chouial, K. Kamli, A. Chibani, and C. Shekhar, Silicon, 10: 2161 (2018).

4. B. Zaidi, B. Hadjoudja, C. Shekhar, B. Chouial, R. Li, M. V. Madhava Rao, S. Gagui, and A. Chibani, Silicon, 8: 513 (2016).

5. B. Zaidi, B. Hadjoudja, H. Felfli, and A. Chibani, Turk. J. Phys., 35: 185 (2011).

6. B. C. Chakravarty, P. N. Vinod, S. N. Singh, and B. R. Chakraborty, Solar Energy Materials and Solar Cells, 73: 59 (2002).

7. B. Zaidi, B. Hadjoudja, B. Chouial, S. Gagui, H. Felfli, A. Magramene, and A. Chibani, Silicon, 7: 293 (2015).

8. B. Zaidi, B. Hadjoudja, B. Chouial, S. Gagui, H. Felfli, and A. Chibani, Silicon, 7: 275 (2015).

9. H. Movla, Optik, 125: 67 (2014).

10. H. Zhang, K. Nakada, and M. Konaga, Thin Solid Films, 628: 214 (2017).

11. B. Zaidi, I. Saouane, and C. Shekhar, Silicon, 10: 975 (2018).

12. M. Agarwal, A. Pawar, N. Wadibhasme, and R. Dusan, Solar Energy, 144: 417 (2017).

13. B. Zaidi, B. Hadjoudja, H. Felfli, B. Chouial, and A. Chibani, Revue de Métallurgie, 108: 443 (2011).

14. M. Burgelman, Thin Solid Films, 515: 6276 (2007).

15. K. Decock, S. Khelifi, and M. Burgelman, Thin Solid Films, 519: 7481 (2011).

16. M. Burgelman, J. Verschraegen, S. Degrave, and P. Nollet, Prog. Photovolt.: Res. Appl., 11: 143 (2004). 